\title{
24. ORGANIC DIAGENESIS OF MIOCENE SEDIMENTS FROM SITE 341, VØRING PLATEAU, NORWAY
}

\author{
David A. Morris, Phillips Petroleum Company, Bartlesville, Oklahoma
}

\section{INTRODUCTION}

As was reported by the author in the Site 341 Report Chapter (this volume), light hydrocarbons were detected in the Tertiary section penetrated at this site located on the V $\phi$ ring Plateau. Gas pockets formed in nearly every core recovered below a depth of 50 meters and shipboard analysis indicated all the gas containing methane and ethane was detected in Miocene age sediments. The middle Miocene cores taken below 400 meters had a pronounced petroliferous odor after they were split, and routine fluoroscopic examination revealed the 33-cc sample recovered from a depth of 446.5-447.0 meters had a bright yellow pinpoint fluorescence. It appeared likely that interstitial soluble hydrocarbons were present in these Miocene pelagic siliceous sediments, and thus drilling was terminated at a depth of 456 meters and the hole was cemented and plugged.

Because the Miocene contained some quantity of soluble hydrocarbons that appeared to increase with depth, a study was undertaken to characterize this material and determine the extent of organic diagenesis of the deep marine Tertiary section in this portion of the V $\phi$ ring Plateau.

\section{ANALYTICAL METHODS}

The shipboard procedure followed for collecting and analyzing the gas samples is described in the section on Organic Geochemical Measurements in Chapter 1 (this volume). Gas samples were collected in specially designed 100-cc evacuated cans, and all gas pockets that formed in the core were sampled so a shipboard analysis could be made and additional analysis made at a later date in our laboratory, their composition was determined by a more sensitive gas chromatograph having a hydrogen flame ionization detector. The isotopic composition was then determined.

A Perkin-Elmer 900 gas chromatograph was utilized in carrying out the laboratory analysis. The valve on the can was connected to an evacuated Perkin-Elmer gas sampling valve fitted with a 1-cc loop. The sample was injected into a 12 foot $\times 1 / 8$ inch $80-100$ mesh Chromasorb 102 column and programmed from $-70^{\circ} \mathrm{C}$ to $100^{\circ} \mathrm{C}$ at a flow rate of $40 \mathrm{ml} / \mathrm{min}$ of helium. The effluent was monitored with a hot wire and hydrogen flame ionization detector arranged in series. Nitrogen, oxygen, argon, methane, and carbon dioxide were detected with the hot wire detector. The higher hydrocarbons were detected with the more sensitive flame ionization detector. Although butenes and pentenes were not detected in the samples, this technique permits their detection.

Carbon isotopic compositions were obtained on a Nier-type $35-\mathrm{cm}$ radius, $90^{\circ}$ sector isotope ratio mass spectrometer. Isotope measurements are made on the $\mathrm{m} / \mathrm{e}=45$ and $\mathrm{m} / \mathrm{e}=44$ ions using carbon dioxide as the working gas. Values are reported using the conventional per mil deviations $(\delta)$ from the $\mathrm{C}^{13} / \mathrm{C}^{12}$ ratio of the Cretaceous belemnite, Belemnitella americana, from the Peedee Formation (PDB). Instrument precision is \pm 0.05 per mil.

Organic carbon samples were combusted to carbon dioxide for mass spectrometry in a vacuum system similar to that described by Craig (1953). Oxidation was carried out at $925^{\circ} \mathrm{C}$ over a copper catalyst in an oxygen atmosphere. Sulfur oxides were removed by a hot manganese dioxide catalyst. Carbon dioxide was purified of water by differential freezing at $-123^{\circ} \mathrm{C}$. Gas components were separated by gas chromatography prior to conversion to carbon dioxide.

The 20-cc sediment samples were collected according to standard shipboard sampling procedures, and care was exercised to minimize contamination and obtain samples representative of the section penetrated. The procedure followed for the geochemical characterization of these samples is shown in Figure 1. The solvents were distilled in glass prior to use.

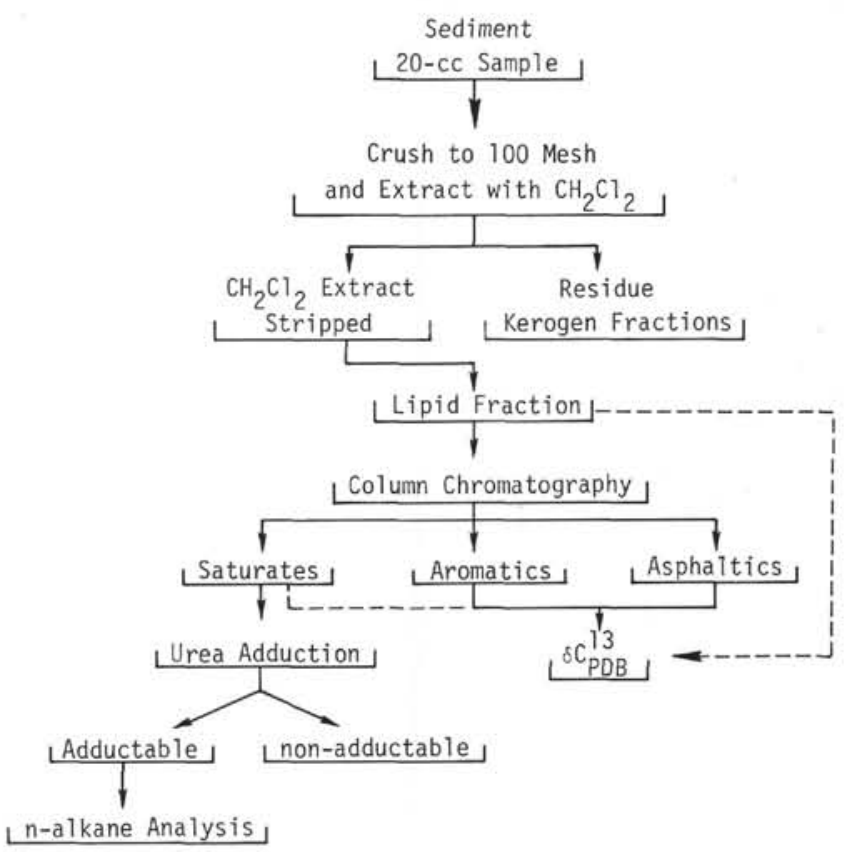

Figure 1. General laboratory procedure followed in characterizing the organic matter in sediment samples. In the case of these samples there was insufficient material to obtain an isotopic value for the lipid and saturates fractions. 


\section{DISCUSSION}

Data resulting from this study are provided in Tables 1 through 4 and Figures 2 and 3. Carbonate content, organic carbon values, quantity of lipid material, and OEP values are provided in Table 1 , along with sampling depth and stratigraphic age. Carbon isotopic values for the aromatic and asphaltic fractions of the sediment samples are provided in Table 2. Compositional analysis and $\delta \mathrm{C}_{\mathrm{POB}}^{13}$ values for the methane component of the canned gas samples are provided in Table 3, along with sampling depth and sedimentary age. Table 4 constitutes a tabulation of weight percents of $n$-alkane by carbon number over the range that could be analyzed for the individual samples. Plots showing the normalized distribution of $n$-alkanes by carbon number for the Pliocene-Pleistocene and middle Miocene samples are provided, respectively, in Figures 2 and 3.

The average Odd-Even Predominance (OEP), which was developed in this laboratory by Scalan and Smith (1970), is a mathematically correct expression of the predominance of odd and even carbon numbers as a function of carbon number for the $n$-alkane series. This value is computed according to the following equation

$$
\mathrm{OEP}=\left[\frac{\mathrm{C}_{i}+6 \mathrm{C}_{i+2}+\mathrm{C}_{i+4}}{4 \mathrm{C}_{i+1}+4 \mathrm{C}_{i+3}}\right]^{(-1)^{i+1}}
$$

As is the case with the Carbon Preference Index (CPI), which was developed by Bray and Evans (1961), an OEP value of unity indicates no predominance, whereas a value greater than unity indicates an oddnumber predominance. An OEP or CPI value less than unity indicates an even-numbered predominance. With increasing depth of burial, organic diagenesis generally increases and OEP and CPI values approach unity. Crude oils commonly have an OEP value close to unity. Erdman (1975a, b) discusses some of the factors affecting organic diagenesis and indicates how OEP can be used as an index for the genesis of petroleum.

The Tertiary section penetrated at Site 341 generally is high in organic matter; the Pliocene-Pleistocene section averages 0.58 weight percent, and the middle Miocene sediments average $1.83 \%$, with organic content generally increasing with depth. All the samples contain some quantity of petroleum-like compounds and many contain sufficient amounts to be classified as source rocks of petroleum according to the criteria of Philippi (1956). However, the OEP values listed in the last column of Table 1 indicate the lipid (oil) fraction has a marked odd-number carbon predominance. This is also evident from the n-alkane plots shown in Figures 2 and 3. The observation that OEP values increase slightly rather than decrease with increasing depth is evidence that organic diagenesis has not proceeded very far in the section. Samples having the lowest OEP values (1.51-1.82) are from the Pliocene-Pleistocene section, and the organic matter in these "glacial" sediments may not be indigenous to this location.

Over the 219.9 through 420.8 meter depth interval, the value of the ratio of lipid (oil) to total organic matter of kerogen averages $31 \%$, whereas that of the underlying section averages only $1.1 \%$. The lipid content of the 200.9-meter-thick interval averages $0.26 \%$, and is comprised by $42 \%$ saturates, whereas the lipid content of the underlying interval averages only $0.02 \%$ and contains only about $24 \%$ saturates. These data suggest that migration has occurred and that some quantity of the lipid material in the section is not indigenous to the interval. Probably migration of material into the interval originated from the surround-

TABLE 1

Organic Geochemical Data for Tertiary Sediments, Site 341

\begin{tabular}{|c|c|c|c|c|c|c|c|c|c|c|c|c|}
\hline \multirow[b]{3}{*}{ Stratigraphic Age } & \multirow{3}{*}{$\begin{array}{c}\text { Depth } \\
\text { Below } \\
\text { Mud } \\
\text { Line } \\
(\mathrm{m})\end{array}$} & \multirow{3}{*}{$\begin{array}{l}\text { Sample } \\
\text { (Interval } \\
\text { in } \mathrm{cm} \text { ) }\end{array}$} & \multicolumn{8}{|c|}{ Weight Percent } & \multirow{3}{*}{$\begin{array}{l}\text { Total } \\
\text { Lipids }\end{array}$} & \multirow{3}{*}{$\begin{array}{c}\begin{array}{c}\text { Odd-Even } \\
\text { Predomi- } \\
\text { nance }\end{array} \\
\text { OEP }\end{array}$} \\
\hline & & & \multicolumn{2}{|c|}{ Carbonate $^{a}$} & \multicolumn{3}{|c|}{ Organic Carbon $^{a}$} & \multicolumn{3}{|c|}{ Lipid Fractions ${ }^{\mathrm{b}}$} & & \\
\hline & & & Carbon & $\mathrm{CaCO}_{3}$ & Total & Lipid & Kerogen & Saturates & Aromatics & Asphaltics & & \\
\hline Pleistocene With & 38.0 & $4, \mathrm{CC}$ & 0.25 & 2.08 & 0.97 & 0.012 & 0.96 & 59.7 & 31.8 & 8.5 & 1.3 & 2.75 \\
\hline \multirow{4}{*}{ Oligocene (Mixed) } & 47.5 & $5, \mathrm{CC}$ & 0.26 & 2.17 & 0.68 & 0.022 & 0.66 & 69.0 & 15.6 & 15.4 & 3.2 & 1.82 \\
\hline & 100.1 & $11-3,60-65$ & 1.23 & 10.25 & 0.43 & 0.021 & 0.41 & 28.4 & 46.0 & 25.6 & 4.8 & 1.59 \\
\hline & 105.2 & $12-6,70-75$ & 1.21 & 10.08 & 0.41 & 0.017 & 0.39 & 35.7 & 42.1 & 22.2 & 4.1 & 2.46 \\
\hline & 161.1 & $16-1,60-65$ & 1.57 & 13.08 & 0.55 & 0.026 & 0.54 & 12.6 & 59.7 & 27.7 & 4.6 & 3.30 \\
\hline Pliocene or & 200.3 & $18-1,75-80$ & 1.10 & 9.17 & 0.49 & 0.012 & 0.48 & 16.3 & 18.1 & 65.6 & 2.5 & 1.51 \\
\hline \multirow[t]{7}{*}{ Pleistocene } & 219.9 & $19-1,140-145$ & 1.32 & 11.00 & 0.45 & 0.195 & 0.43 & 46.1 & 13.9 & 40.0 & 43.4 & 2.03 \\
\hline & 259.9 & $21-2,40-45$ & 1.83 & 15.25 & 0.32 & 0.153 & 0.17 & 43.8 & 25.0 & 31.2 & 47.8 & 2.39 \\
\hline & 317.4 & $24-2,99-104$ & 0.03 & 0.25 & 0.96 & 0.253 & 0.71 & 49.1 & 20.2 & 30.7 & 26.3 & 2.82 \\
\hline & 407.7 & $29-6,120-124$ & 1.02 & 8.50 & 1.55 & 0.293 & 1.26 & 22.1 & 29.9 & 48.0 & 18.9 & 2.04 \\
\hline & 413.5 & $30-4,50-55$ & 0.14 & 1.17 & 1.40 & 0.246 & 1.15 & 54.2 & 15.5 & 30.3 & 17.5 & 2.13 \\
\hline & 420.8 & $31-2,130-135$ & 0.04 & 0.33 & 1.33 & 0.434 & 0.90 & 37.0 & 25.3 & 37.7 & 32.7 & 2.43 \\
\hline & 435.5 & $32-5,105-110$ & 0.24 & 2.00 & 2.00 & 0.018 & 1.98 & 18.2 & 30.2 & 51.6 & 0.9 & 2.26 \\
\hline \multirow[t]{5}{*}{ Middle Miocene } & 436.9 & $32-6,5-10$ & 0.05 & 0.43 & 1.73 & 0.014 & 1.72 & 18.5 & 27.6 & 53.9 & 0.8 & 3.24 \\
\hline & 438.5 & $33-1,135-140$ & 0.03 & 0.25 & 1.89 & 0.022 & 1.87 & 33.7 & 28.1 & 38.2 & 1.1 & 3.05 \\
\hline & 439.2 & $33-2,70-75$ & 0.03 & 0.25 & 2.02 & 0.026 & 1.99 & 40.8 & 21.7 & 37.5 & 1.3 & 2.98 \\
\hline & 446.7 & $34-1,20-25$ & 0.10 & 0.83 & 2.52 & 0.034 & 2.49 & 10.3 & 28.3 & 61.4 & 1.3 & 3.28 \\
\hline & 449.7 & $34-3,20-25$ & 0.06 & 0.50 & 2.04 & 0.022 & 2.02 & 25.3 & 30.3 & 44.4 & 1.1 & 3.27 \\
\hline
\end{tabular}

\footnotetext{
${ }^{a}$ Weight percent with respect to total core sample.

${ }^{b}$ Weight percent with respect to total lipid fraction.

"Weight percent with respect to total organic carbon.
} 
TABLE 2

Carbon Isotopic Compositions of Lipid Fractions Extracted from Tertiary Sediments, Site 341

\begin{tabular}{lllllll}
\hline & & & & \multicolumn{3}{c}{$\delta C_{\text {PDB }}^{13}$} \\
\cline { 5 - 7 } Stratigraphic Age & $\begin{array}{c}\text { Depth (m) Below } \\
\text { Mud Line }\end{array}$ & $\begin{array}{c}\text { Sample } \\
\text { (Interval in cm) }\end{array}$ & Total & Saturates & Aromatics & Asphaltics \\
\hline Pleistocene with & 38.0 & 4, CC & $-^{\mathrm{a}}$ & $-^{\mathrm{a}}$ & -25.4 & -24.5 \\
Oligocene (mixed) & 47.5 & $5, \mathrm{CC}$ & - & - & - & -24.9 \\
\hline & 100.1 & $11-3,60-65$ & - & - & - & -26.4 \\
& 105.2 & $12-6,70-75$ & - & - & -27.2 & -26.9 \\
Pliocene or & 161.1 & $16-1,60-65$ & - & - & -26.0 & -26.9 \\
Pleistocene & 200.3 & $18-1,75-80$ & - & - & -26.1 & -25.3 \\
& 219.9 & $19-1,140-145$ & - & - & - & -25.8 \\
& 259.9 & $21-2,40-45$ & - & - & -26.4 & -25.1 \\
& 317.4 & $24-2,99-104$ & - & - & -27.1 & -27.0 \\
\hline \multirow{3}{*}{ Middle } & 407.7 & $29-6,120-124$ & - & - & -24.6 & -26.3 \\
Miocene & 413.5 & $30-4,50-55$ & - & - & -26.2 & - \\
& 420.8 & $31-2,130-135$ & - & - & -26.1 & -26.6 \\
& 435.5 & $32-5,105-110$ & - & - & -26.2 & - \\
& 436.0 & $32-6,5-10$ & - & - & -25.8 & -24.4 \\
& 438.5 & $33-1,135-140$ & - & - & -25.8 & -26.0 \\
& 439.2 & $33-2,70-75$ & - & - & -25.7 & -26.8 \\
& 446.7 & $34-1,20-25$ & - & - & - & -25.3 \\
& 449.7 & $34-3,20-25$ & - & - & -26.0 & -26.1 \\
\hline
\end{tabular}

${ }^{\mathrm{a}}$ Insufficient sample to obtain an isotopic value.

TABLE 3

Compositional and Isotopic Analysis of Canned Gas Samples ${ }^{\mathrm{a}}$ From Site 341 (Laboratory-Generated Data)

\begin{tabular}{|c|c|c|c|c|c|c|c|c|c|}
\hline \multirow[b]{2}{*}{ Stratigraphic Age } & \multirow{2}{*}{$\begin{array}{l}\text { Depth } \\
\text { Below } \\
\text { Mud Line } \\
\text { (m) }\end{array}$} & \multirow{2}{*}{$\begin{array}{l}\text { Sample } \\
\text { (Interval } \\
\text { in } \mathrm{cm} \text { ) }\end{array}$} & \multicolumn{6}{|c|}{ Composition Normalized Air Free Basis (Mol\%) } & \multirow{2}{*}{$\begin{array}{c}\text { Isotopic } \\
\text { Composition } \\
\text { of Methane } \\
{ }^{\delta} \mathrm{C}_{\mathrm{PDB}}^{13}\end{array}$} \\
\hline & & & $\begin{array}{l}\text { Carbon } \\
\text { Dioxide }\end{array}$ & Methane & Ethane & Propane & $i$-butane & $n$-butane & \\
\hline $\begin{array}{l}\text { Pleistocene with } \\
\text { Oligocene (mixed) }\end{array}$ & 50.5 & $6-2,0$ & 2.17 & 97.82 & 0.01 & $<0.001$ & nd & nd & -87.3 \\
\hline $\begin{array}{l}\text { Pliocene or } \\
\text { Pleistocene }\end{array}$ & $\begin{array}{r}74.0 \\
74.5 \\
80.5 \\
83.0 \\
110.5 \\
163.9 \\
246.5 \\
256.6 \\
277.0 \\
278.5 \\
342.9 \\
\end{array}$ & $\begin{array}{l}8-4,150 \\
8-5,150 \\
9-2,150 \\
9-4,150 \\
12-3,150 \\
16-1,90 \\
20-6,150 \\
21-0,10 \\
22-1,0 \\
25-2,10 \\
25-6,140\end{array}$ & $\begin{array}{c}\text { nd } \\
\text { nd } \\
\text { nd } \\
\text { nd } \\
12.65 \\
\text { nd } \\
0.57 \\
\text { nd } \\
1.49 \\
12.29 \\
5.32 \\
\end{array}$ & $\begin{array}{c}99.94 \\
\text { ndb } \\
99.91 \\
99.99 \\
87.31 \\
\text { nd b }^{b} \\
99.37 \\
\text { ndc }^{c} \\
98.37 \\
87.81 \\
94.59\end{array}$ & $\begin{array}{l}0.06 \\
\text { nd(4) } \\
0.09 \\
0.01 \\
0.04 \\
\text { nd } \\
0.05 \\
\text { nd } \\
0.13 \\
\text { nd } \\
0.07 \\
\end{array}$ & $\begin{array}{c}\text { nd } \\
\text { nd } \\
\text { nd } \\
<0.001 \\
<0.001 \\
\text { nd } \\
0.01 \\
\text { nd } \\
0.01 \\
\text { nd } \\
0.02 \\
\end{array}$ & $\begin{array}{l}\text { nd } \\
\text { nd } \\
\text { nd } \\
\text { nd } \\
\text { nd } \\
\text { nd } \\
\text { nd } \\
\text { nd } \\
\text { nd } \\
\text { nd } \\
\text { nd }\end{array}$ & $\begin{array}{l}\text { nd } \\
\text { nd } \\
\text { nd } \\
\text { nd } \\
\text { nd } \\
\text { nd } \\
\text { nd } \\
\text { nd } \\
\text { nd } \\
\text { nd } \\
\text { nd }\end{array}$ & $\begin{array}{c}-86.6 \\
- \\
-79.4 \\
-80.7 \\
-78.1 \\
- \\
-78.7 \\
-78.1 \\
-77.9 \\
- \\
-78.4 \\
\end{array}$ \\
\hline $\begin{array}{l}\text { Middle } \\
\text { Miocene }\end{array}$ & $\begin{array}{l}370.5 \\
398.5 \\
403.5 \\
455.5\end{array}$ & $\begin{array}{l}27-0,0 \\
28-6,0 \\
29-3,0 \\
34-6,0\end{array}$ & $\begin{array}{r}4.09 \\
7.32 \\
1.92 \\
19.81\end{array}$ & $\begin{array}{l}95.28 \\
91.85 \\
97.88 \\
80.05\end{array}$ & $\begin{array}{l}0.51 \\
0.69 \\
0.16 \\
0.11\end{array}$ & $\begin{array}{l}0.12 \\
0.14 \\
0.04 \\
0.03\end{array}$ & $\begin{array}{c}\text { nd } \\
\text { nd } \\
\text { nd } \\
<0.001\end{array}$ & $\begin{array}{c}\text { nd } \\
\text { nd } \\
\text { nd } \\
<0.001\end{array}$ & $\begin{array}{l}-76.7 \\
-74.3 \\
-75.2 \\
-71.2\end{array}$ \\
\hline
\end{tabular}

Note: nd indicates component was not detected in laboratory analysis.

${ }^{a}$ Gas samples collected according to procedure described under Geochemical Measurements for Site 337 . None of the samples contained sufficient quantity to obtain the isotopic composition of the higher hydrocarbons, nor for the $\mathrm{CO}_{2}$.

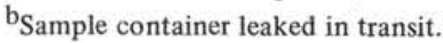

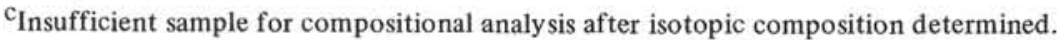

ing sediments. Compaction of the sediments and expulsion of interstitial water probably lead to the migration. McIver $(1971,1973)$ also has cited evidence for the occurrence of hydrocarbon migration in similar age sediments from previous DSDP cores. Apparently such migration can occur rather early in the stage of petroleum migration and may be more common in geochemically immature sediments than expected.
Laboratory analysis of the canned gas samples indicates that in addition to methane, which was present in nearly all samples, ethane also was present and increases in quantity with depth. Below a depth of 342.9 meters in the Miocene, propane is present and also increases in quantity with depth. At a depth of $\mathbf{4 5 5 . 5}$ meters near the bottom of the hole, $i$-butane and $n$ butane were detected. This suggests that some thermal 
TABLE 4

n-Alkane Distribution by Carbon Number for Lipids Extracted from Tertiary Sediments, Site $341^{\text {a }}$

\begin{tabular}{|c|c|c|c|c|c|c|c|c|c|c|c|c|c|c|c|c|c|c|c|}
\hline \multirow{2}{*}{\multicolumn{2}{|c|}{$\begin{array}{c}\text { Depth } \\
\text { Below } \\
\text { Mud Line } \\
\text { (m) }\end{array}$}} & \multicolumn{18}{|c|}{ Normalized Weight Percent } \\
\hline & & 38.0 & 47.5 & 100.1 & 105.2 & 161.1 & 200.3 & 219.9 & 259.9 & 317.4 & 407.7 & 413.5 & 420.8 & 435.5 & 436.0 & 438.5 & 439.2 & 446.7 & 449.7 \\
\hline \multirow{26}{*}{ 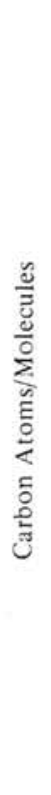 } & 13 & b & - & - & - & - & - & - & - & - & - & 0.16 & - & - & - & - & - & - & - \\
\hline & 14 & - & - & - & - & - & - & - & - & - & - & 0.00 & - & - & - & & - & - & - \\
\hline & 15 & & - & - & - & - & - & 0.62 & - & - & - & 0.27 & - & - & - & - & - & - & - \\
\hline & 16 & & - & - & - & - & - & 0.00 & - & - & - & 0.14 & - & - & 0.28 & - & - & - & - \\
\hline & 17 & & - & & - & 0.44 & - & 0.00 & - & - & - & 0.00 & 0.77 & - & 0.19 & - & 0.39 & 0.21 & 0.21 \\
\hline & 18 & & 0.35 & 0.38 & 1.62 & 0.00 & - & 0.00 & 0.83 & 0.29 & 1.91 & 0.43 & 2.85 & - & 0.21 & - & 1.13 & 0.57 & 0.34 \\
\hline & 19 & 0.93 & 0.31 & 0.44 & 1.62 & 0.00 & 0.32 & 0.00 & 2.12 & 1.08 & 3.27 & 1.33 & 3.99 & & 0.10 & - & 1.29 & 1.12 & 0.99 \\
\hline & 20 & 2.35 & 2.77 & 1.91 & 2.69 & 3.31 & 1.25 & 3.66 & 4.41 & 3.05 & 6.35 & 4.34 & 5.76 & 0.97 & 1.65 & - & 5.66 & 2.39 & 1.75 \\
\hline & 21 & 1.30 & 0.89 & 1.89 & 0.00 & 2.45 & 1.21 & 5.45 & 4.93 & 4.10 & 6.18 & 4.92 & 5.71 & 1.59 & 2.25 & - & 14.01 & 3.35 & 2.58 \\
\hline & 22 & 0.00 & 1.57 & 3.34 & 0.00 & 3.67 & 1.05 & 7.60 & 5.50 & 5.12 & 6.83 & 6.30 & 5.77 & 4.11 & 3.65 & 3.26 & 4.46 & 2.79 & 2.60 \\
\hline & 23 & 2.94 & 3.92 & 6.82 & 7.87 & 6.16 & 0.88 & 9.28 & 7.43 & 7.78 & 6.30 & 5.00 & 5.83 & 3.49 & 3.05 & 6.67 & 6.21 & 4.42 & 4.57 \\
\hline & 24 & 2.48 & 5.27 & 8.19 & 4.74 & 4.55 & 7.22 & 8.21 & 6.56 & 6.49 & 5.93 & 5.74 & 5.17 & 6.02 & 3.76 & 3.76 & 4.33 & 3.19 & 3.51 \\
\hline & 25 & 5.62 & 10.69 & 11.75 & 10.88 & 10.22 & 10.13 & 10.70 & 8.73 & 9.78 & 7.67 & 7.76 & 7.00 & 10.82 & 7.78 & 8.97 & 6.47 & 7.45 & 8.15 \\
\hline & 26 & 2.98 & 3.31 & 10.69 & 5.60 & 5.61 & 10.42 & 7.01 & 6.20 & 6.23 & 6.08 & 6.61 & 5.05 & 10.68 & 5.59 & 5.22 & 4.88 & 4.60 & 6.46 \\
\hline & 27 & 12.80 & 15.46 & 13.74 & 14.89 & 14.24 & 14.64 & 12.30 & 9.98 & 11.68 & 8.45 & 9.46 & 9.10 & 14.09 & 13.52 & 11.95 & 8.93 & 7.80 & 11.00 \\
\hline & 28 & 8.89 & 12.38 & 9.04 & 4.52 & 4.86 & 10.13 & 5.96 & 5.32 & 4.88 & 5.34 & 6.12 & 5.17 & 7.80 & 5.62 & 5.75 & 4.04 & 5.44 & 5.33 \\
\hline & 29 & 18.36 & 14.37 & 10.86 & 14.00 & 14.03 & 14.33 & 10.42 & 10.81 & 11.11 & 10.39 & 12.68 & 11.64 & 13.69 & 18.26 & 15.76 & 11.00 & 15.56 & 14.03 \\
\hline & 30 & 5.96 & 8.79 & 5.38 & 8.30 & 2.77 & 6.62 & 3.67 & 4.07 & 3.55 & 4.28 & 5.25 & 4.23 & 4.67 & 4.61 & 4.70 & 2.78 & 4.29 & 3.78 \\
\hline & 31 & 20.01 & 10.06 & 7.30 & 12.93 & 14.13 & 9.49 & 9.17 & 11.64 & 12.98 & 10.42 & 12.24 & 11.76 & 12.44 & 16.29 & 18.56 & 13.27 & 20.32 & 18.74 \\
\hline & 32 & 3.87 & 3.30 & 2.21 & 2.26 & 2.64 & 3.36 & 2.82 & 2.58 & 2.61 & 2.73 & 2.91 & 2.35 & 2.46 & 2.89 & 2.76 & 2.52 & 2.58 & 2.41 \\
\hline & 33 & 6.87 & 3.34 & 2.68 & 5.82 & 5.62 & 3.49 & 3.13 & 5.69 & 6.86 & 4.29 & 5.07 & 4.17 & 4.16 & 6.86 & 7.27 & 5.24 & 7.05 & 7.12 \\
\hline & 34 & 1.29 & 1.01 & 0.74 & 2.26 & 1.92 & 2.31 & - & 1.02 & 0.97 & 1.13 & 0.83 & 0.70 & 0.63 & 0.25 & 2.44 & 0.97 & 1.31 & 1.68 \\
\hline & 35 & 1.99 & 0.35 & 0.56 & - & 2.42 & 0.52 & - & 1.11 & 0.80 & 1.83 & 1.79 & 1.74 & 1.31 & 1.73 & 2.93 & 2.33 & 2.89 & 2.58 \\
\hline & 36 & 1.36 & 1.85 & 1.28 & - & 0.00 & 2.65 & - & 0.68 & 0.49 & 0.42 & 0.53 & 0.41 & 0.81 & 0.72 & - & - & 1.07 & 0.34 \\
\hline & 37 & & - & 0.54 & - & 0.96 & - & - & 0.27 & 0.13 & 0.10 & - & 0.58 & 0.16 & 0.64 & - & - & 0.51 & 0.41 \\
\hline & 38 & - & $\ldots$ & 0.26 & - & - & - & - & 0.11 & - & - & - & 0.15 & - & - & - & - & 1.09 & 1.37 \\
\hline
\end{tabular}

aDSDP core identification provided in Table 1.

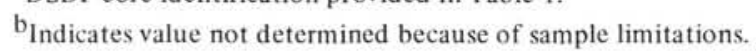




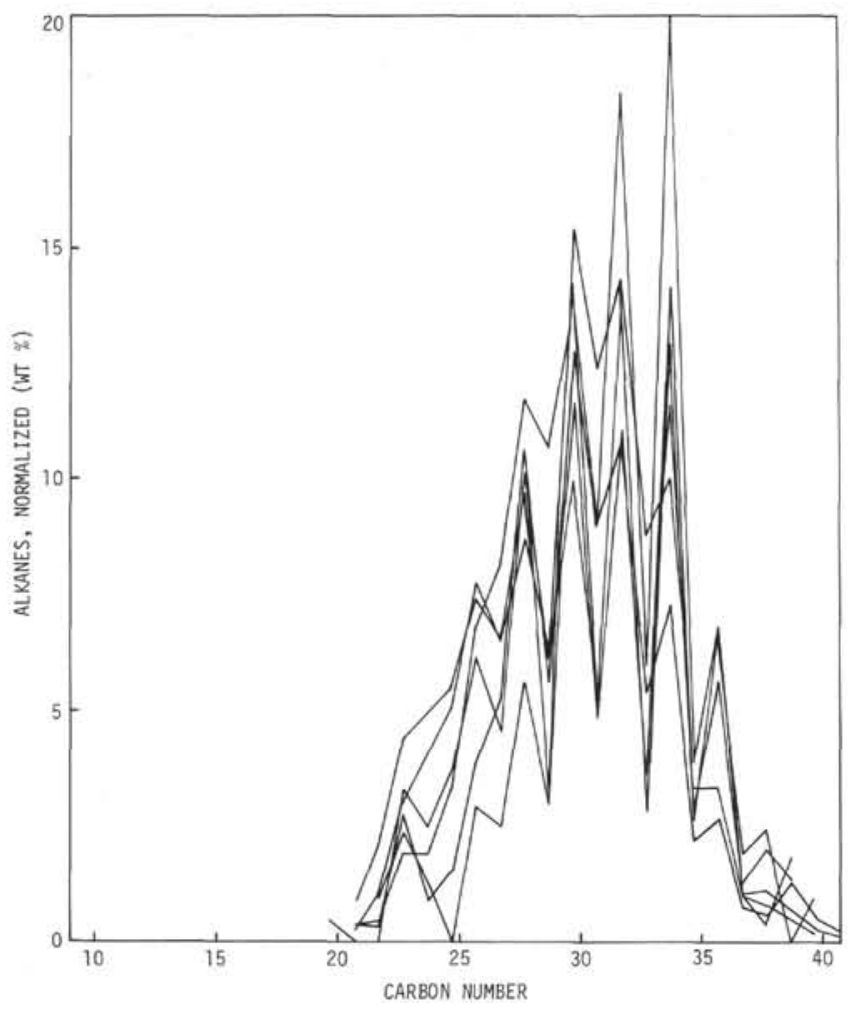

Figure 2. Normalized n-alkane plots for Pliocene-Pleistocene sediments from Site 341.

degradation of organic matter has taken place in these sediments, and is becoming more pronounced with depth.

As shown in Table $3, \delta \mathrm{C}_{\mathrm{PDB}}^{13}$ values for methane become progressively isotopically heavier with depth. At a depth of 50.5 meters in the Pleistocene, methane has a value of -87.5 , whereas at a depth of 455.5 meters in the Miocene the methane has a value of -71.2 . Although very light isotopic values for methane have been attributed to a bacterial origin (Rosenfeld and Silverman, 1959), this gas is believed to have originated primarily from abiogenic degradation of the organic matter and represents the early products of organic diagenesis. A theoretical study of the chemical kinetic effects on carbon isotopic compositions by Smith et al. (1971, p. 21-24) predicts a progressive change in isotopic compositions with depth toward heavier values as organic diagenesis becomes more pronounced. The measured isotopic values for methane in this Tertiary section are quite similar to values predicted from this kinetic model.

\section{CONCLUSIONS}

Although petroleum genesis is indicated to be in an early stage in the Miocene section, there is evidence that abiogenic diagenesis has begun and some light hydrocarbons have been generated. Evidence suggests the first product of this abiogenic diagenesis was an isotopically light methane. As organic diagenesis increased with depth, isotopically heavier methane and a greater quantity of ethane and higher homologs were

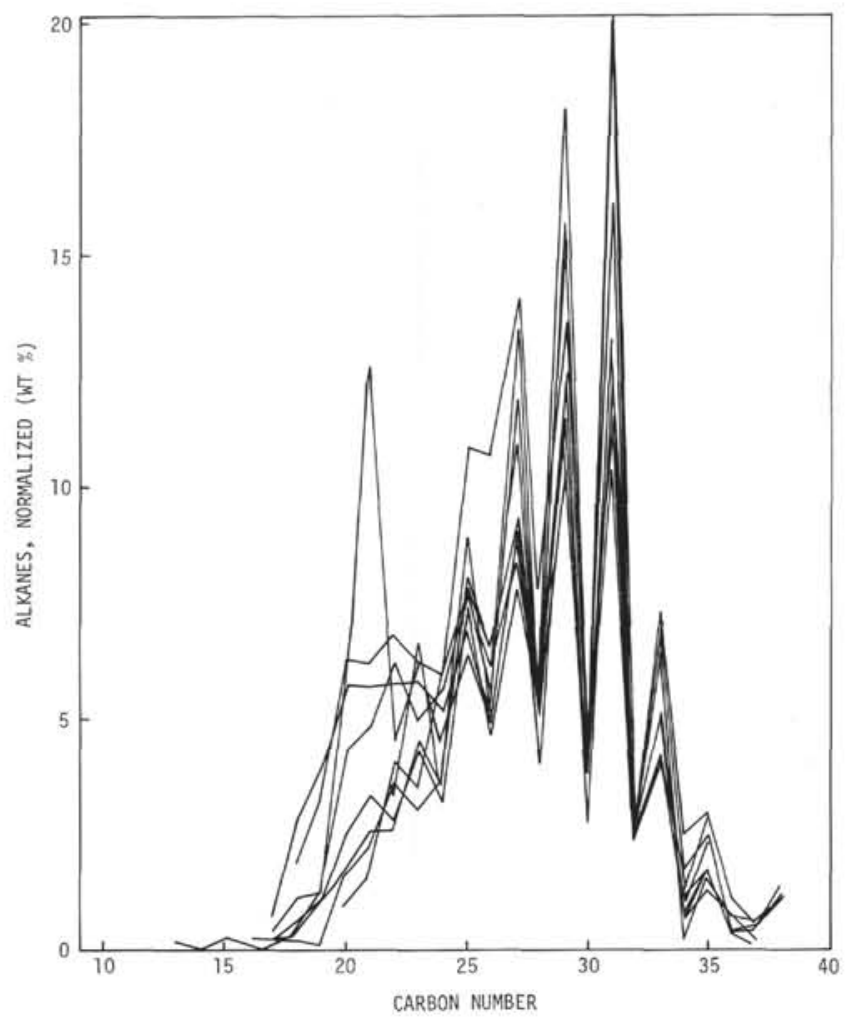

Figure 3. Normalized n-alkane plots for middle Miocene sediments from Site 341 .

produced. Generation of liquid oil is not very far advanced in the Miocene, although clearly some lipid material has migrated. However, the quantity is small and certainly is not of economic importance. Probably this movement of lipids was caused by expulsion of pore fluid as the sediment was compacted.

\section{ACKNOWLEDGMENTS}

The author expresses his appreciation to K.S. Schorno, W.J. Hines, C.G. Long, and M.E. Smith, who provided assistance in this study and who were so helpful in assembling the geochemical equipment used on Leg 38; to J.G. Erdman, who offered helpful suggestions throughout this study; and to members of the JOIDES Organic Geochemical Panel, who made my participation in Leg 38 possible.

\section{REFERENCES}

Bray, E.E and Evans, E.D., 1961. Distribution of $n$-paraffins as a clue to recognition of source beds: Geochim. Cosmochim. Acta, v. 22, p. 2-15.

Craig, H., 1953. The geochemistry of the stable carbon isotopes: Geochim. Cosmochim. Acta, v. 3, p. 53-92.

Erdman, J.G., 1975a. Geochemical formation of oil: In Fisher, A.G. and Judson, S. (Eds.), Petroleum and global tectonics: Princeton (Princeton University Press), p. 225248.

1975b. Time and temperature relations affecting the origin, expulsion and preservation of oil and gas: Paper 1, Panel Discussion 3, 9th World Petrol. Congr, Tokyo.

McIver, R.D., 1971. JOIDES Cores. Evidence of migration of hydrocarbons in Pleistocene sediments of the Shatsky Plateau: western Pacific Ocean: In Fisher, A.G., Heezen, 
B.C., et al., 1971, Initial Reports of the Deep Sea Drilling Project, Volume 6: Washington (U.S. Government Printing Office), p. 1327-1329.

1973. JOIDES Cores. Geochemical significance of gas and gasoline range hydrocarbons and other organic matter in Miocene samples from Site 134-Balearic Abyssal Plain: In Ryan, W.B.F., Hsü, K.J., et al., Initial Reports of the Deep Sea Drilling Project, Volume 13: Washington (U.S. Government Printing Office), p. 813-816.

Philippi, G.T., 1956. Identification of oil source beds by chemical means: Internatl. Geol. Congr., 20th Mexico, Section III, p. 25-38.
Rosenfeld, W.D. and Silverman, S.R., 1959. Carbon isotope fractionation in bacterial production of methane: Science, v. 130 , p. 1658 .

Scalan, R.S. and Smith J.E., 1970. An improved measure of the Odd-Even Predominance in the normal alkanes of sediment extracts and petroleum: Geochim. Cosmochim. Acta, v. 34 , p. 611-620.

Smith, J.E., Erdman, J.G., and Morris, D.A., 1971. Migration, accumulation and retention of petroleum in the earth: 8th World Petrol. Congr. Proc., v. 2, p. 13-26. 